\title{
Cloning of genes encoding colicin E2 in Lactococcus lactis subspecies lactis and evaluation of the colicin-producing transformants as inhibitors of Escherichia coli 0157:H7 during milk fermentation
}

\author{
S. M. Liu, D. M. Miller, and R. F. Roberts ${ }^{1}$ \\ Department of Food Science, The Pennsylvania State University, University Park 16802
}

\begin{abstract}
Colicin E2 (ColE2) is a proteinaceous bacterial toxin produced by some strains of Escherichia coli and other members of the Enterobacteriaceae that exhibits inhibitory activity against some strains of E. coli O157:H7. A 2.0-kb DNA fragment, containing the ColE2 structural gene $c e a B$ and immunity gene ceiB from $E$. coli NCTC 50133 (pColE2-P9), was cloned into the lactococcal plasmid vector pNZ2103. The lysis gene, celB, was not cloned. The plasmid, pLR-E2, encoding the cloned genes was transformed into E. coli DH5 $\alpha$ and Lactococcus lactis ssp. lactis LM0230 and PN-1 using electroporation. The bacteriocin ColE2 was expressed in transformants of both E. coli and L. lactis ssp. lactis. Secretion of ColE2 into media was verified by spot-onlawn assays and measurement of ColE2 activity in the growth medium of transformants. The level of ColE2 produced by transformants containing pLR-E2 was similar to that produced by the parental strain, E. coli NCTC 50133 (pColE2-P9). Evaluation of a ColE2-producing transformant of L. lactis ssp. lactis as a starter culture revealed that, although ColE2 was produced by transformants and could be detected in milk during fermentation, the inhibitory activity of ColE2 against E. coli $\mathrm{O} 157: \mathrm{H} 7$ was significantly decreased in milk compared with buffered growth medium.
\end{abstract}

Key words: colicin, Escherichia coli O157:H7

\section{INTRODUCTION}

Bacteriocins are biologically active proteins that are widely produced by bacteria and serve as part of the microbial defense system (Riley and Wertz, 2002). Unlike antibiotics, which have a broad-spectrum bactericidal effect, the killing range of bacteriocins is narrower, affecting only bacteria closely related to the producing strains (Riley and Wertz, 2002). Bacteriocins may have applications in food preservation and safety, and there

Received June 16, 2010.

Accepted November 25, 2010.

${ }^{1}$ Corresponding author: Rfr3@psu.edu has been considerable interest in use of bacteriocinproducing lactic acid bacteria (LAB) for controlling spoilage microorganisms and pathogens during dairy fermentations (Roberts et al., 1992; Roberts and Zottola, 1993; O'Sullivan et al., 2002; Gálvez et al., 2007). Nisin, a bacteriocin produced by Lactococcus lactis, is a generally recognized as safe (GRAS) additive and is approved for meats, poultry, sauces, and processed cheese (FDA, 1994; USDA, 2002). Nisin is inhibitory to gram-positive pathogens such as Clostridium botulinum, Listeria monocytogenes, and Staphylococcus aureus, and may be used to prevent quality defects such as late blowing of Swiss cheese caused by Clostridium spp. (Zottola et al., 1994; Delves-Broughton, 2005).

Although nisin can be used to inhibit some grampositive pathogens, gram-negative pathogens such as Escherichia coli O157:H7 are also a concern in fermented dairy products. Dineen et al. (1998) studied survival of $E$. coli $\mathrm{O} 157: \mathrm{H} 7$ as a postfermentation contaminant in buttermilk, sour cream, and yogurt. Escherichia coli O157:H7 was inoculated at $10^{3} \mathrm{cfu} / \mathrm{g}$ or $\mathrm{mL}$ in commercial samples and held at $4^{\circ} \mathrm{C}$ for $35 \mathrm{~d}$. The pathogen was recovered up to $12 \mathrm{~d}$ in yogurt, $28 \mathrm{~d}$ in sour cream, and $35 \mathrm{~d}$ in buttermilk. Persistence of E. coli O157:H7 in fermented dairy products may lead to foodborne illnesses as the infectious dose has been estimated to be $<100$ cells (Meng et al., 2001).

A bacteriocin inhibitory to $E$. coli $\mathrm{O} 157: \mathrm{H} 7$ could be used as part of a multi-hurdle approach to improve the safety of fermented dairy products. Although LAB do not produce bacteriocins inhibitory to E. coli O157:H7, genes encoding for bacteriocins in gram-negative microorganisms could be transferred to a food-grade host.

Previous research in our laboratory assessed the inhibitory activity of a range of colicins against diarrheagenic E. coli, including strains of serotypes O15:H-, O26: (H11, H-), and O111 (H8, H11, H-) and O157:H7 (Murinda et al., 1996). Inhibitory activity assays of Group A colicins, including A, E1-E8, K, N, S4, and MccB17, and Group B colicins B, Ia, Ib, M, V, G, H, and D revealed 2 Group A colicins, E2 and E8, exhibited inhibitory activity against all 11 strains of $E$. coli O157:H7 and 12 of 15 (80\%) non-O157:H7 strains 
evaluated. Several other researchers have evaluated the inhibitory activity of colicin E2 (ColE2), and findings suggest that the susceptibility to ColE2 is a variable trait among E. coli O157:H7 strains (Jordi et al., 2001; Schamberger and Diez-Gonzalez, 2002). Because of the inhibitory activity observed in our previous work, ColE2 was chosen for use in these experiments.

The bacteriocin ColE2 is produced by E. coli, whose production and mode of action has been studied extensively (Jakes, 1982; Pugsley and Schwartz, 1983, 1984; Cole et al., 1985; Sugiyama and Itoh, 1993). The colicin operon is carried on a plasmid and includes a structural gene $(c e a B)$ encoding for the bacteriocin, an immunity gene $(c e i B)$ that protects the producer cell from the toxin, and a lysis gene $(c e l B)$ that leads to death of the producer cell and release of ColE2 into the surrounding medium (Cascales et al., 2007). Sensitivity of gram-negative microorganisms to ColE2 is conferred by the binding of the bacteriocin to an outer membrane receptor - the TonB-dependent vitamin $\mathrm{B}_{12}$ transporter, BtuB (Cascales et al., 2007). After transport across the membrane, ColE2 acts as an endonuclease, degrading the DNA of the sensitive cell. Optimum ColE2 activity occurs between pH 6.5 and 7.0; thus, ColE2 could be applied to inhibit proliferation of E. coli $\mathrm{O} 157: \mathrm{H} 7$ early in fermentations when the $\mathrm{pH}$ and incubation temperature of the milk is favorable for pathogen growth (Jakes, 1982).

One of the challenges of producing ColE2 in a LAB such as Lactococcus lactis ssp. lactis stems from differences in the transport mechanisms of bacteriocins in gram-negative and gram-positive microorganisms (O'Sullivan et al., 2002). In gram-negative microorganisms, ColE2 is thought to be released into the surrounding medium after CelB-mediated lysis of the producer cell. Expression of $c e l B$ leads to changes in the cell envelope and results in activation of OmpLA, an outer membrane phospholipase A (Cascales et al., 2007). Mutation or deletion of the lysis protein has been shown to interfere with release, and in such cases, the colicin remains in the cytoplasm (Cascales et al., 2007). In gram-positive microorganisms, secretion does not occur through cell lysis, and is not a lethal event for the cell. Instead, secretion is dependent on a signal peptide, which typically contains conserved double-glycine regions, and is mediated by a bacteriocin-specific transport system or the sec-dependent export pathway (Wandersman, 1992; Pugsley, 1993).

Although ColE2 does not contain a signal peptide to direct secretion of the protein, it is predicted to contain 6 double glycine regions at the $\mathrm{N}$ terminus, which may function in a manner analogous to a signal peptide. Thus, ColE2 may be secreted by a gram-positive host without lysis of the producer cell. This feature is im- portant if the genes encoding for colicin production are to be transferred to and expressed by a LAB such as $L$. lactis ssp. lactis during fermentation.

In the present study, genes encoding ColE2 from $E$. coli were cloned and expressed in transformants of $L$. lactis ssp. lactis. Secretion of the ColE2 by the transformants in the absence of a signal peptide was confirmed, and the bactericidal activity of the ColE2-producing transformant was evaluated against E. coli O157:H7 during fermentation of milk.

\section{MATERIALS AND METHODS}

\section{Bacterial Strains, Media, and Plasmids}

The bacterial strains and plasmids used in this study are listed in Table 1. Escherichia coli strains were grown in Luria Broth (Miller's formulation, Difco Laboratories, Detroit, MI) at $37^{\circ} \mathrm{C}$ for 8 to $12 \mathrm{~h}$. Lactococcus lactis ssp. lactis strains were routinely grown at $30^{\circ} \mathrm{C}$ for 8 to $12 \mathrm{~h}$ in M17 broth (Difco) supplemented with $0.5 \%$ lactose (M17L) or glucose (M17G). Chloramphenicol $(10 \mu \mathrm{g} / \mathrm{mL}$ for E. coli strains and $5 \mu \mathrm{g} / \mathrm{mL}$ for L. lactis ssp. lactis strains) was added as a selective agent for transformants.

\section{Molecular Cloning, Reagents, and Enzymes}

Plasmid DNA was isolated from E. coli NCTC 50133 using Wizard plus Minipreps or Midipreps Purification Systems (Promega, Madison, WI). Restriction endonucleases (HindIII and PstI) were purchased from Promega and used according to the manufacturer's instructions. Cloning procedures and E. coli manipulations were performed according to standard protocols (Sambrook et al., 1989).

The ColE2 gene $(c e a B)$ and its immunity gene $(c e i B)$ on plasmid DNA (pColE2-P9) of NCTC 50133 were amplified using the polymerase chain reaction (PCR) with the following primers: $(+)$ 5'-GACCGACGTCATGAGCGGTGGCGATGGACGC-3' and (-) 5'-CCTGAAGCTTTCAGCCCTGTTTAAATCCTGACTTACC- 3 '. The underlined regions represent restriction sites for HindIII and PstI that were designed in the forward and reverse primers, respectively. The PCR was performed using a PE9600 thermal cycler (Perkin Elmer, Foster City, CA) using the following conditions: $95^{\circ} \mathrm{C}$ for $1 \mathrm{~min}$ and $72^{\circ} \mathrm{C}$ for $4 \mathrm{~min}, 25$ cycles. A PCR amplicon of $2.0 \mathrm{~kb}$ was cloned into pNZ2103 (Platteeuw et al., 1996), resulting in pLR-E2. Insertion of DNA in the clone was verified by sequencing the insert on pLR-E2 using the Taq DyeDeoxy Terminator Cycle Sequencing System (ABI Prism, Perkin Elmer, Foster City, CA). Oligonucleotide primers (Penn State Core 
Table 1. Strains and plasmids used in this work

\begin{tabular}{|c|c|c|}
\hline Strain or plasmid & Relevant feature $^{1}$ & Reference or source \\
\hline \multicolumn{3}{|l|}{ Escherichia coli } \\
\hline NCTC 50102 & ColE2-sensitive & Murinda et al., 1996; Pugsley and Oudega, 1987 \\
\hline NCTC 50133 & Contains pColE2-P9, produces colicin & Murinda et al., 1996; Pugsley and Oudega, 1987 \\
\hline NCTC 50156 & ColE2-sensitive, $\mathrm{Cm}^{\mathrm{r}}$ & Murinda et al., 1996; Pugsley and Oudega, 1987 \\
\hline NCTC 50164 & ColE2-sensitive & Murinda et al., 1996; Pugsley and Oudega, 1987 \\
\hline $\mathrm{DH} 5 \alpha$ & Plasmid-free, ColE2-sensitive & Karen J. Miller ${ }^{2}$ \\
\hline LM0230 & Plasmid-free, $\mathrm{Lac}^{-} \mathrm{Prt}^{-} \mathrm{Cm}^{\mathrm{s}}$ & Efstathiou and McKay, 1977 \\
\hline LM0230 (pLR-E2) & $\mathrm{Lac}^{+} \mathrm{Prt}^{-} \mathrm{Cm}^{\mathrm{r}} \mathrm{ColE} 2^{\mathrm{r}}$ & This work \\
\hline $\mathrm{PN}-1(\mathrm{pPN}-1)$ & $\mathrm{Lac}^{+} \mathrm{Prt}^{-} \mathrm{Cm}^{\mathrm{s}}$ & Caldwell et al., 1996 \\
\hline PN-1 (pPN-1, pLR-E2) & $\mathrm{Lac}^{+} \mathrm{Prt}^{-} \mathrm{P}_{\text {lac }} \mathrm{T}_{p e p N} \mathrm{Cm}^{\mathrm{r}} \mathrm{ColE}^{\mathrm{r}}$ & This work \\
\hline \multicolumn{3}{|l|}{ Plasmid } \\
\hline pNZ2103 & $\mathrm{P}_{l a c} \mathrm{~T}_{p e p N} \mathrm{Cm}^{\mathrm{r}}$ & Platteeuw et al., 1996 \\
\hline $\mathrm{pPN}-1$ & $\mathrm{P}_{\text {lac }} \mathrm{T}_{p e p N} \mathrm{Cm}^{\mathrm{s}}$ & Caldwell et al., 1996 \\
\hline
\end{tabular}

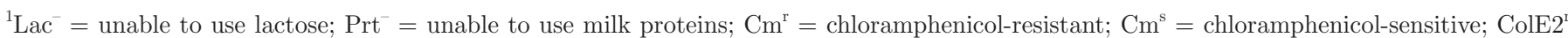
$=$ colicin E2-resistant; $\mathrm{P}_{l a c}=$ promoter of the lactose operon $(l a c) ; \mathrm{T}_{p e p N}=$ terminator of peptidase $\mathrm{N}$ gene.

${ }^{2}$ Gift from K. J. Miller, Department of Food Science, The Pennsylvania State University.

Genomics Facility, University Park, PA) for sequencing were designed at approximately 300-bp intervals based on the available DNA sequence information (Cole et al., 1985).

Electrotransformation of E. coli DH5 $\alpha$ and Lactococcus lactis ssp. lactis LM0230 and PN-1 was performed using the protocol of Holo and Nes (1989) with the following modifications: $200 \mathrm{ng}$ DNA was mixed with $100 \mu \mathrm{L}$ of cell suspension in a $0.4-\mathrm{cm}$ cuvette, and the electric pulse was applied at $2.5 \mathrm{kV}, 300 \Omega, 25 \mu \mathrm{F}$ (time constant ca. 6-7 ms) using a BioRad GenePulser (BioRad Laboratories, Hercules, CA). Transformants were selected by plating on media containing chloramphenicol as described previously.

Stability of pLR-E2 in L. lactis PN-1 (pLR-E2) was measured by comparing the population of $\mathrm{PN}-1$ (pLR-E2) grown on selective and nonselective media following multiple transfers on a nonselective medium. Briefly, L. lactis PN-1 (pLR-E2) was cultured in M17G broth at $30^{\circ} \mathrm{C}$ for $8 \mathrm{~h}$, and the total population was determined on plate counts on M17G agar incubated at $30^{\circ} \mathrm{C}$ for 24 to $48 \mathrm{~h}$. Viable counts were also conducted on M17L agar containing $10 \mu \mathrm{g}$ of chloramphenicol/ $\mathrm{mL}$, which allowed enumeration of cells containing both pPN-1 and pLR-E2. The difference between the cell counts on M17G and M17L with chloramphenicol was used to demonstrate compatibility between pLR-E2 and $\mathrm{pPN}-1$.

\section{Assay of ColE2 Expression and Activity}

Overlay assays against ColE2-sensitive and resistant E. coli indicator strains (Table 1) were used to test for
ColE2 expression in E. coli $\mathrm{DH} 5 \alpha$ and L. lactis ssp. lactis transformants containing pLR-E2 (Pugsley and Oudega, 1987). To evaluate secretion of ColE2, "spot on the lawn" assays were performed using cell-free supernatants (CFS), which were prepared by centrifugation $(5,000 \times g$ for $10 \mathrm{~min})$ of transformant cultures (Pugsley and Oudega, 1987). The resulting supernatant was filtered $(0.20 \mu \mathrm{m}$, Corning Laboratory, Corning, NY), and residual chloramphenicol was removed from the CFS by dialysis $(14,000$ MWCO, Sigma, St. Louis, MO). Removal of residual chloramphenicol was verified by assay against sensitive strains. To detect ColE2 activity, $10 \mu \mathrm{L}$ of CFS was spotted on Luria soft agar $(0.8 \%)$ seeded with $10^{6} \mathrm{cfu}$ of indicator strain $/ \mathrm{mL}$, and following incubation, the plates were scored for zones of inhibition.

To assess the level of ColE2 activity, $10 \mu \mathrm{L}$ of CFS or serially 2-fold diluted CFS (diluted in sterile deionized water) was spotted on Luria soft agar $(0.8 \%)$ seeded with $10^{6}$ cfu of sensitive indicator strain NCTC 50154/ $\mathrm{mL}$. Relative inhibitory activity units (RU) were described as $\mathrm{n}$, where $\mathrm{n}$ was the highest 2 -fold dilution $\left(2^{\mathrm{n}}\right)$ causing inhibition of the indicator strain.

\section{Secretion of ColE2 into Medium}

In our efforts to determine if ColE2 was released into the surrounding medium as the result of cell lysis, the activity of aldolase, a cytoplasmic enzyme, was quantified in broth fermented with pLR-E2 transformants using a standard enzyme test kit (Boehringer Mannheim, Indianapolis, IN). Briefly, $2.5 \mathrm{~mL}$ of substrate (fructose-1,6-diphosphate) solution (30 $\mathrm{mM} ; 560 \mathrm{mM}$ 
collidine buffer, $\mathrm{pH}$ 7.4, $3 \mathrm{mM}$ moniodoacetate), $50 \mu \mathrm{L}$ of NADH solution $(24 \mu M$ yeast $\beta-\mathrm{NADH})$, a $10-\mu \mathrm{L}$ mixture of glyceraldehyde-3-phosphate/triosephosphate isomerase/lactate dehydrogenase, and $200 \mu \mathrm{L}$ of supernatant of cultured broth $(12,000 \times g ; 5 \mathrm{~min})$ were pipetted into a cuvette, mixed well, and incubated at $37^{\circ} \mathrm{C}$. Absorbance at $344 \mathrm{~nm}$ was measured after 5 and 20 min of incubation at $37^{\circ} \mathrm{C}$ using a DU 650 spectrophotometer (Beckman Instruments, Inc., Fullerton, $\mathrm{CA}$ ). The decrease in absorbance, which is proportional to the oxidation of NADH, was used to calculate aldolase activity in the samples (Garver et al., 1984).

\section{Inhibition of E. coli O157:H7 in Fermented Milk by ColE2-Producing Transformants}

Reconstituted skim milk ( $10 \%$ milk solids not fat, MSNF) was prepared by dissolving nonfat dry milk solids (Maryland and Virginia Milk Producer Assoc. Inc., Laurel, MD) supplemented with $0.5 \%$ yeast extract in water. Following heat treatment at $100^{\circ} \mathrm{C}$ for $5 \mathrm{~min}$, the milk was cooled to $30^{\circ} \mathrm{C}$ and inoculated with $10^{6} \mathrm{cfu}$ of L. lactis ssp. lactis $\mathrm{PN}-1$ or $\mathrm{PN}-1$ (pLR-E2)/mL along with $10^{4}$ cfu of $E$. coli (NCTC 50154 or O157:H7) $/ \mathrm{mL}$. Milk inoculated with only the E. coli strain (NCTC 50154 or O157:H7) served as a negative control. During incubation, the $\mathrm{pH}$, concentration of ColE2 and $E$. coli counts were determined every hour. Escherichia coli were quantified by plating serial dilutions on MacConkey Sorbitol Agar (Difco) with incubation at $35^{\circ} \mathrm{C}$ for $24 \mathrm{~h}$.

In order to further evaluate the influence of the suspension medium on ColE2, activity assays were performed using deionized water, M17L or pasteurized milk as diluents using the described previously procedure with E. coli NCTC 50154 and E. coli O157:H7.

All experiments were run in duplicate. Where indicated, means were compared by $t$-tests using Minitab (version 15, Minitab, Inc., State College, PA) with $\alpha$ $=0.05$.

\section{RESULTS}

\section{Construction and Characterization of pLR-E2}

Plasmid pNZ2103 is a high-copy-number plasmid (40-50 copies per chromosome), which includes a controllable L. lactis ssp. lactis lacA promoter, a L. lactis ssp. lactis pepN terminator, the $L$. lactis ssp. lactis promiscuous pSH71 replicon, and the chloramphenicol resistance gene (cat gene) from staphylococcal plasmid pC94 (Platteeuw et al., 1996). Plasmid pLR-E2 was constructed by inserting a 2.0-kb PCR amplicon ob- tained from pColE2-P9 DNA containing ceaB and ceiB into pNZ2103 (Figure 1a). Transformants containing pLR-E2 demonstrated inhibitory activity against the sensitive indicator, E. coli NCTC 50154 (Figure 1b). The presence and orientation of the ceaB and ceiB insertion in pLR-E2 was verified by PCR, and by sequencing $3 \mathrm{~kb}$ of DNA of pLR-E2 that included ceaB, $c e i B$, as well as flanking regions (data not shown). The sequence data matched with that published for ceaB and $c e i B$ and pNZ2103 (Cole et al., 1985; van Rooijen, 1993).

Because L. lactis ssp. lactis LM0230 is unable to utilize lactose and is unable to grow well in milk, pLR$\mathrm{E} 2$ was electroporated into L. lactis $\mathrm{PN}-1$. Lactococcus lactis ssp. lactis PN-1 (pPN-1, pLR-E2) could grow in milk (supplemented with yeast extract) and produce ColE2. Co-existence of pPN-1 and pLR-E2 in L. lactis ssp. lactis $\mathrm{PN}-1$ was confirmed by agarose gel electrophoresis, and production of ColE2 by the transformant was determined by overlay assays against sensitive indicator strains as described above (data not shown). When grown at $30^{\circ} \mathrm{C}$ for $8 \mathrm{~h}$ on M17L with and without chloramphenicol, L. lactis ssp. lactis PN-1 (pLR-E2) produced 8 and $12 \mathrm{RU}$ of colicin $/ \mathrm{mL}$, respectively (data not shown). Both pPN-1 and pLR-E2 were stably maintained over at least 10 generations on a nonselective medium (data not shown).

\section{Expression of ColE2 in E. coli and $L$. lactis ssp. lactis}

Expression of ColE2 was initially evaluated by determining the inhibitory activity of culture supernatants against a set of ColE2-sensitive and resistant indicator strains (Table 2). The bacteriocin ColE2 was produced by pLR-E2-containing transformants of E. coli $\mathrm{DH} 5 \alpha$, L. lactis ssp. lactis LM0230, and L. lactis ssp. lactis PN1. No inhibitory activity was detected in E. coli DH5 , L. lactis ssp. lactis LM0230, or L. lactis ssp. lactis PN-1 without pLR-E2. The relative concentration of ColE2 in the CFS of E. coli NCTC 50133 and the transformants was determined by comparing the inhibitory activity against the universal colicin indicator NCTC 50154. Eight RU of ColE2 were produced by pLR-E2-containing transformants of L. lactis ssp. LM0230 and E. coli DH5 $\alpha$ (Figures 2a, b, c). The transformants produced ColE2 at a level similar to that of E. coli NCTC 50133 (pColE2-P9) from which the genes were derived.

Aldolase is a cytoplasmic enzyme and was used as an indicator of cell leakage. Aldolase activity was not detected in supernatants of E. coli NCTC 50133 (pColE-P9) during the first $6 \mathrm{~h}$ of incubation, when the ColE2 activity was increasing (Figure 2a). An increase in 
a)
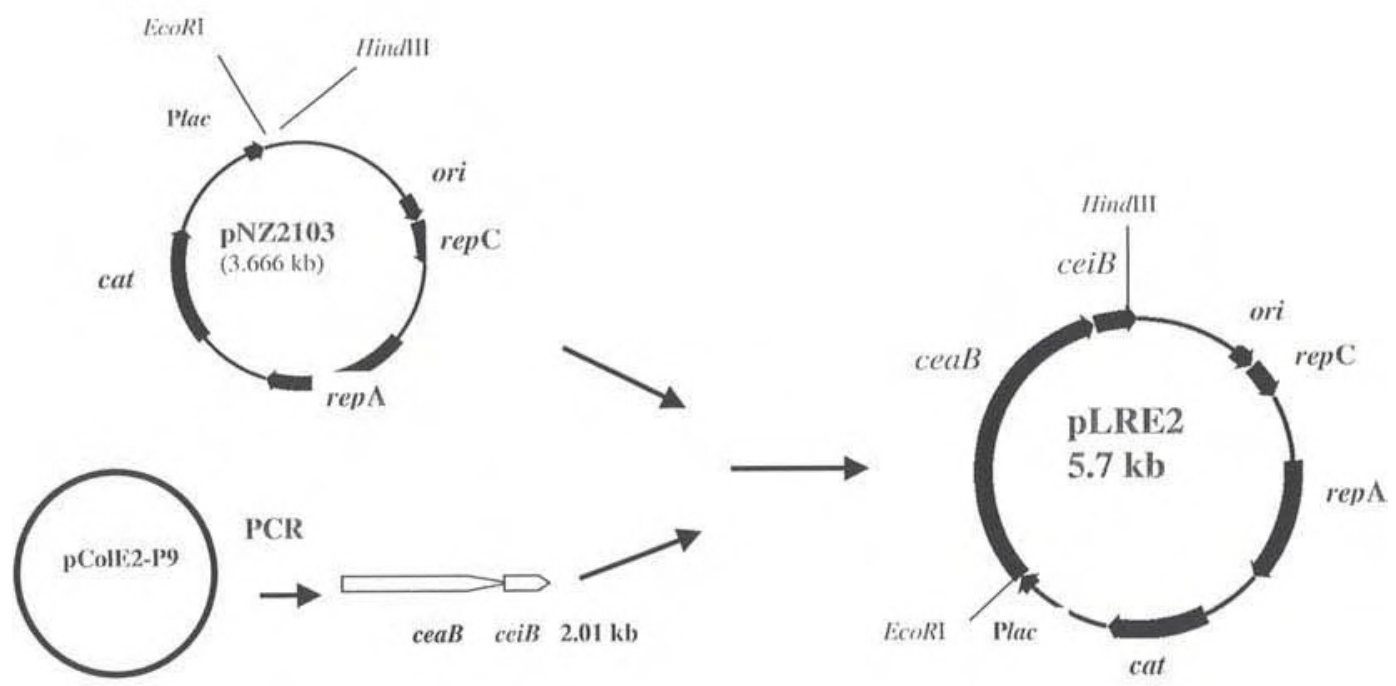

b)

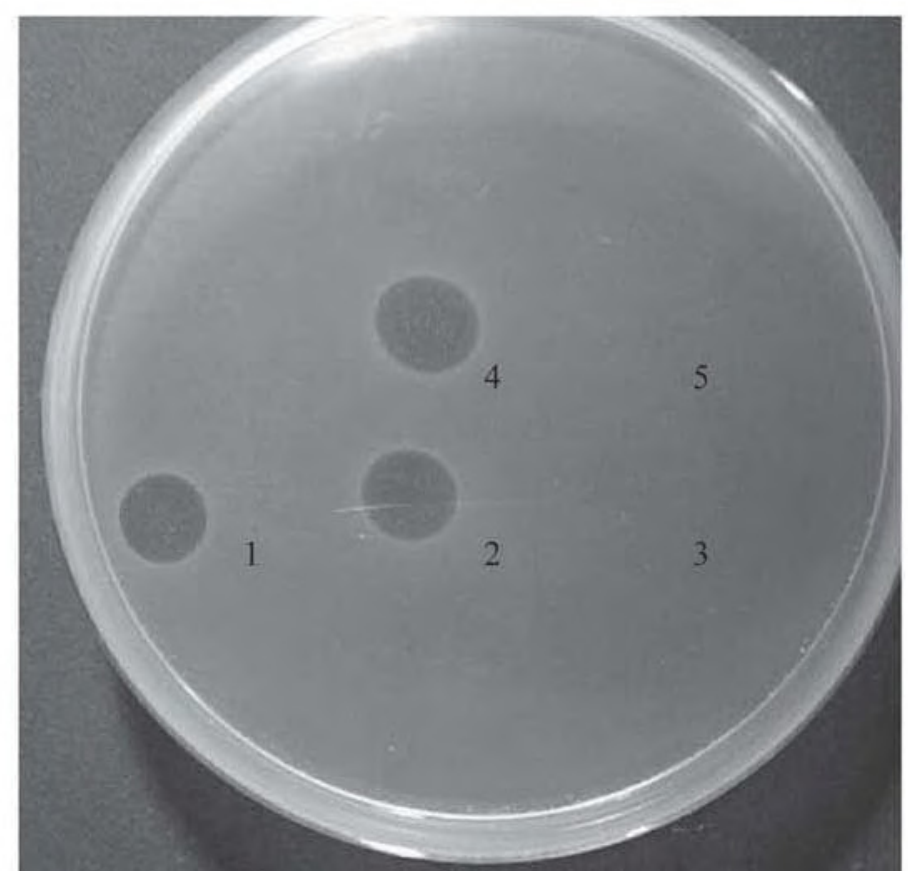

Figure 1. (a) Construction of pLR-E2 from pColE2-P9 and pNZ2103; (b) inhibitory activity of cell-free supernatants of (1) Escherichia coli

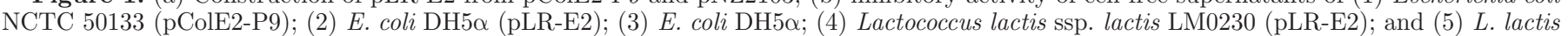
ssp. lactis LM0230 (plasmid-free) against the ColE2-sensitive indicator E. coli NCTC 50154.

aldolase activity in E. coli NCTC 50133 coincided with a plateau in absorbance at $600 \mathrm{~nm}$, which indicated the culture had reached stationary phase. In both E. coli DH5 $\alpha$ (pLR-E2) and LM0230 (pLR-E2) transformants, ColE2 activity was detected before an increase in aldolase activity was observed (Figures $2 \mathrm{~b}$ and 2c).

\section{Inhibition of E. coli by L. lactis PN-1 (pLR-E2) in Milk}

Figure 3 is a representative graph of the reduction in $E$. coli counts during incubation with $L$. lactis ssp. lactis PN-1 (pLR-E2). Counts of E. coli NCTC 50154 decreased significantly $(3 \mathrm{log})$ during the first hour of 
Table 2. Inhibition of colicin E2-sensitive and insensitive indicator strains by Escherichia coli DH5 $\alpha$, Lactococcus lactis ssp. lactis LM0230, L. lactis ssp. lactis PN-1, and their transformants containing pLR-E2

\begin{tabular}{|c|c|c|c|c|c|c|}
\hline \multirow{3}{*}{$\begin{array}{l}\text { ColE2-producing } \\
\text { and control strains }\end{array}$} & \multicolumn{6}{|c|}{ Indicator $^{1}$} \\
\hline & \multicolumn{3}{|c|}{ ColE2-insensitive } & \multicolumn{3}{|c|}{ ColE2-sensitive } \\
\hline & E2 & 02 & 56 & $\mathrm{DH} 5 \alpha$ & 54 & 64 \\
\hline E. coli NCTC 50133 (pColE2-P9) & $-^{2}$ & - & - & + & + & + \\
\hline E. coli $\mathrm{DH} 5 \alpha$ & - & - & - & - & - & - \\
\hline E. coli DH5 $\alpha$ (pLR-E2) & - & - & - & + & + & + \\
\hline L. lactis ssp. lactis LM0230 & - & - & - & - & - & - \\
\hline L. lactis lactis LM0230 (pLR-E2) & - & - & - & + & + & + \\
\hline L. lactis lactis $\mathrm{PN}-1$ (pPN-1) & - & - & - & - & - & - \\
\hline L. lactis lactis $\mathrm{PN}-1$ (pPN-1, pLR-E2) & - & - & - & + & + & + \\
\hline
\end{tabular}

${ }^{1}$ Indicator strains E2: E. coli NCTC 50133 (pColE2-P9); 02: E. coli NCTC 50102; 56: E. coli NCTC 50156;

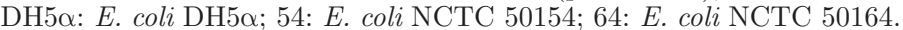

${ }^{2}+=$ ColE2 inhibited indicators and formed a clear zone; $-=$ ColE2 did not inhibit indicators.

incubation with L. lactis ssp. lactis $\mathrm{PN}-1$ (pLR-E2) and then plateaued during the next $5 \mathrm{~h}$ (Figure 3). After the first hour of incubation, counts of E. coli NCTC 50154 cocultured with $L$. lactis ssp. lactis PN-1 (pLRE2) were significantly lower than when cultured in the presence of L. lactis ssp. lactis $\mathrm{PN}-1$. The population decrease appeared to be related to low $\mathrm{pH}$ as well as ColE2 activity as an approximately 2-log decrease in E. coli NCTC 50154 counts occurred with L. lactis ssp. lactis PN-1. Lactococcus lactis ssp. lactis PN-1 (pLRE2) did not inhibit E. coli O157:H7 during coculture in milk, even though the strain produced about $8 \mathrm{RU}$ of ColE $2 / \mathrm{mL}$ (Figure 4 ). With the exception of counts at $6 \mathrm{~h}$, no significant difference was observed in the population of $E$. coli $\mathrm{O} 157: \mathrm{H} 7$ during coculture with L. lactis ssp. lactis $\mathrm{PN}-1$ and L. lactis ssp. lactis $\mathrm{PN}-1$ (pLR-E2). Lactococcus lactis ssp. lactis $\mathrm{PN}-1$ and $\mathrm{PN}-1$ (pLR-E2) decreased the $\mathrm{pH}$ of milk at similar rates during the fermentation (Figures 3 and 4).

To determine if the lack of inhibition observed was a result of components present in the milk, deionized water, M17L, and thermally processed milk were used as dilution buffers to measure ColE2 activity. Susceptibility of strains to ColE2 was found to vary because the indicator strain NCTC 50154 was more sensitive to ColE2 than E. coli $\mathrm{O} 157: \mathrm{H} 7$, irrespective of the diluent. With indicator strain E. coli NCTC 50154, ColE2 activities of 8,8 , and $5 \mathrm{RU} / \mathrm{mL}$ in deionized water, M17L, and milk, respectively, were observed. The ColE2 activities with E. coli O157:H7 were lower, with values of 4,3 , and 2 , in deionized water, M17L, and milk, respectively. These results indicate that strains vary with respect to ColE2 susceptibility and that unidentified components of milk inhibit the activity of ColE2.

\section{DISCUSSION}

This study demonstrated that genes associated with bacteriocin production from a gram-negative microorganism could be cloned, expressed, and secreted by a gram-positive microorganism in the absence of a lysis protein (CelB) and without addition of a signal peptide. In the present work, genes associated with ColE2 production (ceaB and ceiB) were transferred to L. lactis ssp. lactis, which is used in the manufacture of buttermilk, sour cream, and various cheeses (Johnson and Steele, 2001). The level of ColE2 production by the colicin-producing transformants of $L$. lactis ssp. lactis LM0230 was similar to that of E. coli NCTC 50133, from which the ColE2-encoding genes (pColE2-P9) were derived.

Secretion of ColE2 proteins into the surrounding medium by E. coli NCTC 50133 and the pLR-E2 transformants occurred before cell leakage was observed, as indicated by the absence of aldolase activity in culture supernatants (Figure 2a, b, and c). The mechanism proposed for secretion of ColE2 from $E$. coli involves release of the colicin caused by the lysis protein, CelB (Pugsley and Rosenbusch, 1981; Pugsley and Schwartz, 1983, 1984; Cole et al., 1985; Kanoh et al., 1991; Cavard and Oudega, 1992). Braun et al. (1994) found inactivation of $c e l B$ resulted in decreased release of colicin from the cells, compared with cells containing intact celB.

Cell lysis during protein secretion is rare in gramnegative bacteria and has not been observed in grampositive bacteria (Wandersman, 1996). In most secretion systems (Murphy and Beckwith, 1996), proteins are synthesized initially with signal peptides that direct secretion. For periplasmic or secreted proteins, these signals are located at the N-terminal region of 
a)

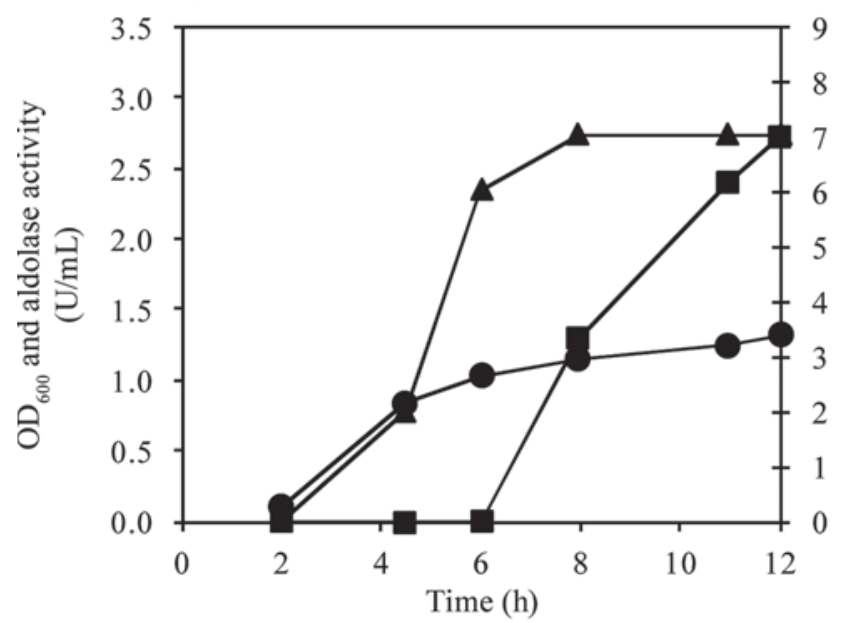

b)

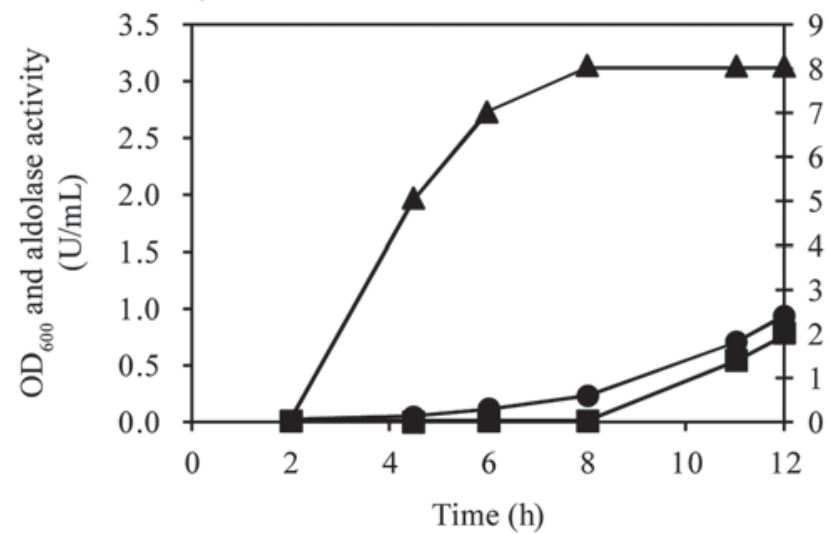

c)

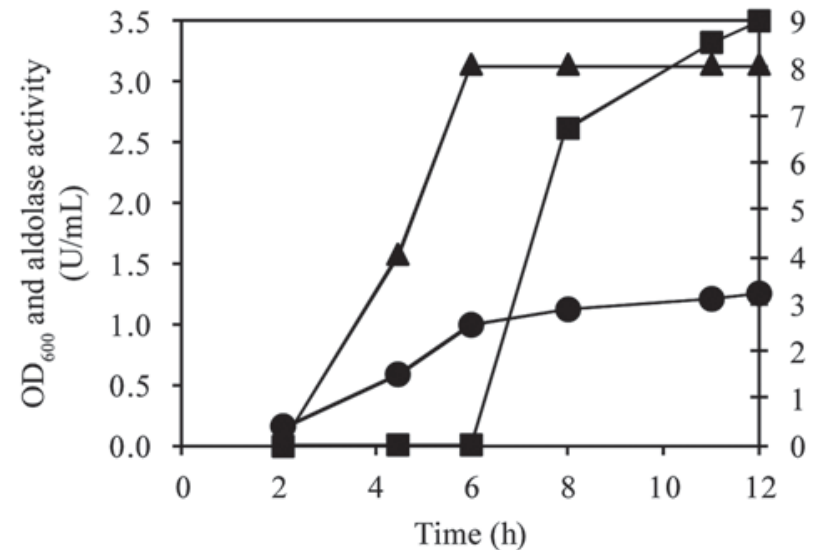

Figure 2. Growth and colicin E2 (ColE2) production by (a) Escherichia coli NCTC 50133 (pColE2-P9); (b) E. coli DH5a (pLRE2); and (c) Lactococcus lactis ssp. lactis LM0230 (pLR-E2). Aldolase activity was used as an indicator of cell lysis. Growth (optical density at $600 \mathrm{~nm}, \mathbf{0})$, aldolase activity $(\mathrm{U} / \mathrm{mL}, \boldsymbol{\square})$, and ColE2 activity, expressed in relative inhibitory units $(\mathrm{RU}, \mathbf{\Lambda})$.

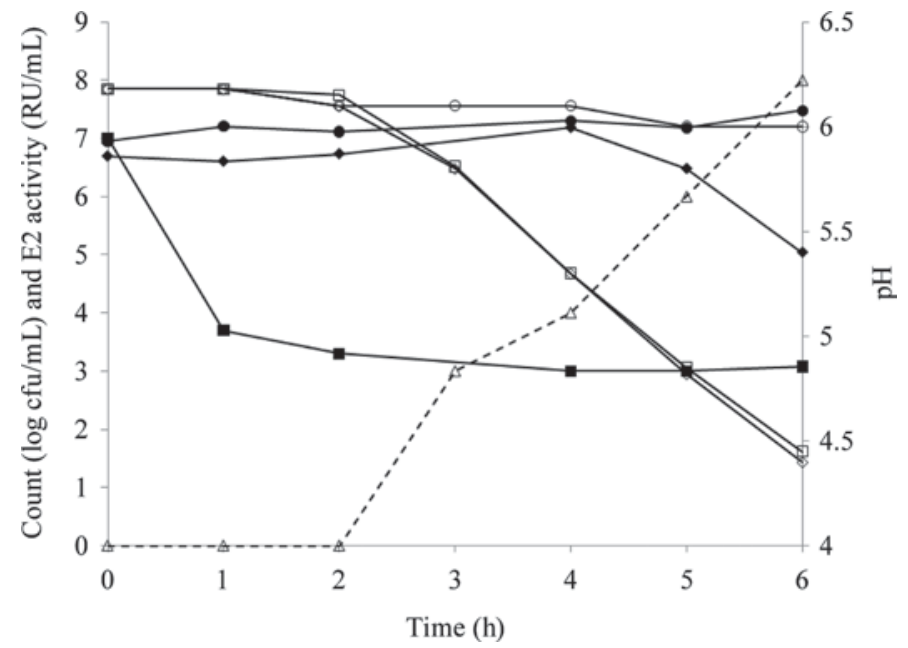

Figure 3. The pH, colicin E2 (ColE2) activity (expressed in relative inhibitory units, RU), and Escherichia coli NCTC 50154 counts in milk and milk fermented with Lactococcus lactis ssp. lactis PN-1 or PN-1 (pLR-E2), incubated at $30^{\circ} \mathrm{C}$ until coagulation was observed. No ColE2 activity was observed in milk fermented with L. lactis ssp. lactis PN-1. Milk was inoculated with E. coli NCTC $50154(\bullet) ; L$. lactis $\mathrm{PN}-1+$ E. coli NCTC $50154(\bullet)$; and L. lactis PN-1 (pLR-E2) + E. coli NCTC $50154(\boldsymbol{\square})$, then incubated at $30^{\circ} \mathrm{C}$ until coagulation was observed. Viable counts of E. coli NCTC 50154 were determined on Sorbitol MacConkey agar (SMAC).. Open symbols are used to represent $\mathrm{pH}$ readings, except for ColE2 activity, which is represented by $(\Delta)$.

the protein and cleaved during export. These export signals, along with the attached proteins are recognized within the cell by the export apparatus or transporter proteins, such as ATP-binding cassette family proteins (ABC transporters).

Amino acid sequence analysis in silico showed GGXGX regions repeating 6 times at the $\mathrm{N}$ terminus of $\mathrm{CeaB}$ (data not shown), which may contribute to transport. Wandersman (1996) proposed that proteins secreted by ABC-transporter pathways contain a domain, which consists of a conserved glycine-rich sequence (GGXG), repeating 4 to 6 times in different proteins (Pugsley, 1993; Wandersman, 1996; van Belkum et al., 1997; Rodríguez et al., 2003). This domain may play a critical role as an internal chaperone allowing better signal recognition in CeaB secretion. Furthermore, a doubleglycine region has been found to function in secretion of colicin V in LAB (van Belkum et al., 1997). Additional experiments are required to identify the mechanism(s) of secretion. Several reports have described the secretion of bacteriocins using heterologous ABC transporters in other species (Allison et al., 1995a,b; van Belkum and Stiles, 1995; McCormick et al., 1996). In addition, van Belkum et al. (1997) reported successful cloning and expression of colicin $\mathrm{V}$ in L. lactis using a signal 


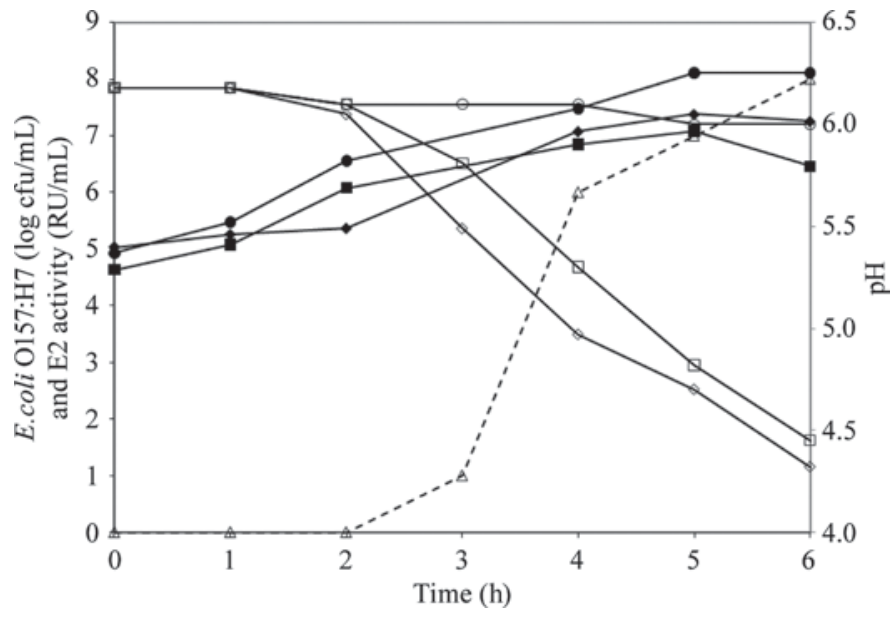

Figure 4. The pH, colicin E2 (ColE2) activity (expressed in relative inhibitory units, RU), and Escherichia coli O157:H7 counts in milk and milk fermented with Lactococcus lactis ssp. lactis PN-1 or PN-1 (pLR-E2) incubated at $30^{\circ} \mathrm{C}$ until coagulation was observed. Milk was inoculated with E. coli $\mathrm{O} 157: \mathrm{H} 7(\bullet)$; L. lactis ssp. lactis $\mathrm{PN}-1+$ E. coli $\mathrm{O} 157: \mathrm{H} 7$ ( ); and L. lactis ssp. lactis PN-1 (pLR-E2) + E. coli $\mathrm{O} 157: \mathrm{H} 7(\boldsymbol{\square})$, and incubated at $30^{\circ} \mathrm{C}$ until coagulation was observed. Viable counts of E. coli O157:H7 were determined by plating on Sorbitol MacConkey agar (SMAC). Open symbols represent $\mathrm{pH}$ readings. No ColE2 activity was observed in milk fermented with L. lactis ssp. lactis PN-1. ColE2 activity for $4 \mathrm{~A}+\mathrm{PN}-1$ (pLR-E2) is represented by $(\Delta)$.

peptide from leucocin A. In the present work, ColE2 was expressed and secreted by a gram-positive microorganism in the absence of lysis proteins and without addition of a signal peptide. The transformants of $E$. coli DH5o and L. lactis ssp. lactis LM0230 containing pLR-E2 demonstrated ColE2 activities similar to E. coli NCTC 50133. The level of ColE2 produced may be due to the strong lacA promoter used to start transcription or alternative secretion systems in the new host.

Cloning and expression of ColE2 in L. lactis ssp. lactis allowed evaluation of the transformant as a biopreservative for use in fermented dairy foods. Although the ColE2-producing transformant L. lactis ssp. lactis PN-1 (pLR-E2) produced up to $8 \mathrm{RU}$ of $\mathrm{ColE} 2 / \mathrm{mL}$ during fermentation of milk and was able to inhibit the ColE2-sensitive indicator strain E. coli NCTC 50154, it failed to inhibit growth of E. coli O157:H7 (Figures 3 and 4). Additional experiments suggest this failure was due to differences in strain susceptibility and components of milk. Loss or reduction of bacteriocin activity has been widely reported in food matrices and may be caused by a host of factors, including food constituents, pH, and proteases (Gálvez et al., 2007). The results of this study clearly indicate PN-1 (pLR-E2) would not be an effective inhibitor of $E$. coli $\mathrm{O} 157: \mathrm{H} 7$ in fermented dairy foods.

\section{CONCLUSIONS}

The findings of this study indicate colicin-associated genes from gram-negative microorganisms can be cloned, expressed, and secreted in a gram-positive foodgrade host. Our results show variability in the susceptibility of E. coli strains to ColE2 and the influence of the matrix on ColE2 activity. This study highlights the potential application of bacteriocins as biopreservatives in a multi-hurdle approach for improvement of food quality and safety.

\section{ACKNOWLEDGMENTS}

Appreciation is extended to L. L. McKay (professor emeritus, University of Minnesota) for the gift of strains and for helpful discussion regarding this research. This research was funded, in part, by a special grant for milk safety administered by the USDA.

\section{REFERENCES}

Allison, G. E., C. Ahn, M. E. Stiles, and T. R. Klaenhammer. 1995a. Utilization of the leucocin A export system in Leuconostoc gelidum for production of a Lactobacillus bacteriocin. FEMS Microbiol. Lett. 131:87-93.

Allison, G. E., R. W. Worobo, M. E. Stiles, and T. R. Klaenhammer. 1995b. Heterologous expression of the lactacin $\mathrm{F}$ peptides by Carnobacterium piscicola LV17. Appl. Environ. Microbiol. 61:1371-1377.

Braun, V., H. Pilsl, and P. Gross. 1994. Colicins: Structures, modes of action, transfer through membranes, and evolution. Arch. Microbiol. 161:199-206.

Caldwell, S. L., D. J. McMahon, C. J. Oberg, and J. R. Broadbent. 1996. Development and characterization of lactose-positive Pediococcus species for milk fermentation. Appl. Environ. Microbiol. 62:936-941.

Cascales, E., S. K. Buchanan, D. Duché, C. Kleanthous, R. Lloubès, K. Postle, M. Riley, S. Slatin, and D. Cavard. 2007. Colicin biology. Microbiol. Mol. Biol. Rev. 71:158-229.

Cavard, D., and B. Oudega. 1992. General introduction to the secretion of bacteriocins. Pages 297-305 in Bacteriocins, Microcins, and Lantibiotics. R. James, C. Lazdunski, and F. Pattus, ed. SpringerVerlag, Berlin Heidelberg, Germany.

Cole, S. T., B. Saint-Joanis, and A. P. Pugsley. 1985. Molecular characterisation of the colicin E2 operon and identification of its products. Mol. Gen. Genet. 198:465-472.

Delves-Broughton, J. 2005. Nisin as a food preservative. Food Aust. $57: 525-532$.

Dineen, S. S., K. Takeuchi, J. E. Soudah, and K. J. Boor. 1998. Persistence of Escherichia coli O157: H7 in dairy fermentation systems. J. Food Prot. 61:1602-1608.

Efstathiou, J. D., and L. L. McKay. 1977. Inorganic salts resistance associated with a lactose-fermenting plasmid in Streptococcus lactis. J. Bacteriol. 130:257-265.

FDA. 1994. Nisin. 184:1538 in Code of Federal Regulations. Food and Drug Administration, Washington, DC.

Gálvez, A., H. Abriouel, R. L. López, and N. B. Omar. 2007. Bacteriocin-based strategies for food biopreservation. Int. J. Food Microbiol. 120:51-70.

Garver, G. L., L. A. Kaplan, and A. J. Pesce. 1984. Clinical Chemistry: Theory Analysis and Correlations. CV Mosby, St. Louis, MO.

Holo, H., and I. F. Nes. 1989. High-frequency transformation, by electroporation, of Lactococcus lactis ssp. cremoris grown with gly- 
cine in osmotically stabilized media. Appl. Environ. Microbiol. 55:3119-3123.

Jakes, K. S. 1982. The mechanism of action of colicin E2, colicin E3 and cloacin DF13. Pages 131-167 in Molecular Action of Toxin and Viruses. P. Cohen and S. van Heyningen, ed. Elsevier Biomedical Press, Amsterdam, the Netherlands.

Johnson, M. E., and J. L. Steele. 2001. Fermented Dairy Products. Pages 651-664 in Food Microbiology: Fundamentals and Frontiers. 2nd ed. M. P. Doyle, L. R. Beuchat, and T. J. Montville, ed. ASM Press, Washington, DC.

Jordi, B. J., K. Boutaga, C. M. van Heeswijk, F. van Knapen, and L. J. Lipman. 2001. Sensitivity of Shiga toxin-producing Escherichia coli (STEC) strains for colicins under different experimental conditions. FEMS Microbiol. Lett. 204:329-334.

Kanoh, S., H. Masaki, S. Yajima, T. Ohta, and T. Uozumi. 1991. Signal peptide of the colicin E2 lysis protein causes host cell death. Agric. Biol. Chem. 55:1607-1614.

McCormick, J. K., R. W. Worobo, and M. E. Stiles. 1996. Expression of the antimicrobial peptide carnobacteriocin B2 by a signal peptide-dependent general secretory pathway. Appl. Environ. Microbiol. 62:4095-4099.

Meng, J., M. P. Doyle, T. Zhao, and S. Zhao. 2001. Enterohemorrhagic Escherichia coli. Pages 103-214 in Food Microbiology: Fundamentals and Frontiers. 2nd ed. M. P. Doyle, L. R. Beuchat, and T. J. Montville, ed. ASM Press, Washington, DC.

Murinda, S. E., R. F. Roberts, and R. A. Wilson. 1996. Evaluation of colicins for inhibitory activity against diarrheagenic Escherichia coli strains, including serotype O157:H7. Appl. Environ. Microbiol. 62:3196-3202

Murphy, C. K., and J. Beckwith. 1996. Export of proteins to the cell envelope in Escherichia coli. Pages 967-978 in Escherichia coli and Salmonella: Cellular and Microbiology. F. C. Neidhardt, ed. ASM Press, Washington, DC.

O'Sullivan, L., R. P. Ross, and C. Hill. 2002. Potential of bacteriocinproducing lactic acid bacteria for improvements in food safety and quality. Biochimie 84:593-604.

Platteeuw, C., I. van Alen-Boerrigter, S. Van Schalkwijk, and W. M. de Vos. 1996. Food-grade cloning and expression system for Lactococcus lactis. Appl. Environ. Microbiol. 62:1008-1013.

Pugsley, A. P. 1993. The complete general secretory pathway in Gramnegative bacteria. Microbiol. Mol. Biol. Rev. 57:50-108.

Pugsley, A. P., and B. Oudega. 1987. Methods for studying colicins and their plasmids. Pages 105-161 in Plasmids: A Practical Approach. K. G. Hardy, ed. IRL Press, Washington, DC.

Pugsley, A. P., and J. P. Rosenbusch. 1981. Release of colicin E2 from Escherichia coli. J. Bacteriol. 147:186-192.

Pugsley, A. P., and M. Schwartz. 1983. Expression of a gene in a 400-base-pair fragment of colicin plasmid ColE2-P9 is sufficient to cause host cell lysis. J. Bacteriol. 156:109-114.
Pugsley, A. P., and M. Schwartz. 1984. Colicin E2 release: Lysis, leakage or secretion? Possible role of a phospholipase. EMBO J. $3: 2393-2397$.

Riley, M. A., and J. E. Wertz. 2002. Bacteriocins: Evolution, ecology, and application. Annu. Rev. Microbiol. 56:117-137.

Roberts, R. F., and E. A. Zottola. 1993. Shelf-life of pasteurized process cheese spreads made from Cheddar cheese manufactured with a nisin-producing starter culture. J. Dairy Sci. 76:1829-1836.

Roberts, R. F., E. A. Zottola, and L. L. Mckay. 1992. Use of a nisinproducing starter culture suitable for cheddar cheese manufacture. J. Dairy Sci. 75:2353-2363.

Rodríguez, J. M., M. I. Martínez, N. Horn, and H. M. Dodd. 2003. Heterologous production of bacteriocins by lactic acid bacteria. Int. J. Food Microbiol. 80:101-116.

Sambrook, J., E. F. Fritsch, and T. Maniatis. 1989. Molecular Cloning. Cold Spring Harbor Laboratory Press, Cold Spring Harbor, NY.

Schamberger, G. P., and F. Diez-Gonzalez. 2002. Selection of recently isolated colicinogenic Escherichia coli strains inhibitory to Escherichia coli O157:H7. J. Food Prot. 65:1381-1387.

Sugiyama, T., and T. Itoh. 1993. Control of ColE2 DNA replication: in vitro binding of the antisense RNA to the Rep mRNA. Nucleic Acids Res. 21:5972-5977.

USDA. 2002. Safe and suitable ingredients used in the production of meat and poultry products. FSIS Directive 7120.1. United States Department of Agriculture, Washington, DC.

van Belkum, M. J., and M. E. Stiles. 1995. Molecular characterization of genes involved in the production of the bacteriocin leucocin A from Leuconostoc gelidum. Appl. Environ. Microbiol. 61:35733579 .

van Belkum, M. J., R. W. Worobo, and M. E. Stiles. 1997. Doubleglycine-type leader peptides direct secretion of bacteriocins by ABC transporters: Colicin V secretion in Lactococcus lactis. Mol. Microbiol. 23:1293-1301.

van Rooijen, R. J. 1993. Characterization of the Lactococcus lactis lactose genes and regulation of their expression. PhD Thesis. Wageningen Agricultural University, Wageningen, the Netherlands.

Wandersman, C. 1992. Secretion across the bacterial outer membrane. Trends Genet. 8:317-322.

Wandersman, C. 1996. Secretion across the bacterial outer membrane. Pages 955-966 in Escherichia coli and Salmonella: Cellular and Microbiology. F. C. Neidhardt, ed. ASM Press, Washington, DC.

Zottola, E. A., T. L. Yezzi, D. B. Ajao, and R. F. Roberts. 1994. Utilization of cheddar cheese containing nisin as an antimicrobial agent in other foods. Int. J. Food Microbiol. 24:227-238. 